\title{
Yuhushiella deserti gen. nov., sp. nov., a new member of the suborder Pseudonocardineae
}

\author{
Jun Mao, ${ }^{1} \dagger$ Jian Wang, ${ }^{2,3}$ † Huan-Qin Dai, ${ }^{2}$ Zhi-Dong Zhang, ${ }^{1}$ \\ Qi-Yong Tang, ${ }^{1}$ Biao Ren, ${ }^{2} \mathrm{Na}$ Yang, ${ }^{2}$ Michael Goodfellow, ${ }^{4}$ \\ Li-Xin Zhang ${ }^{2,5}$ and Zhi-Heng Liu ${ }^{2}$ \\ ${ }^{1}$ Institute of Microbiology, Xinjiang Academy of Agricultural Sciences, Urumqi 830091, Xinjiang \\ Uigur Autonomous Region, PR China \\ ${ }^{2}$ Institute of Microbiology, Chinese Academy of Sciences, Beijing 100190, PR China \\ ${ }^{3}$ Guangdong Key Laboratory of Marine Materia Medica, South China Sea Institute of Oceanology, \\ Chinese Academy of Sciences, Guangzhou 510301, PR China \\ ${ }^{4}$ School of Biology, University of Newcastle, Newcastle upon Tyne NE1 7RU, UK \\ ${ }^{5}$ SynerZ Pharmaceuticals Inc., Lexington, MA 02421, USA
}

Correspondence

Zhi-Heng Liu

zhliu@sun.im.ac.cn

Li-Xin Zhang

Izhang03@gmail.com

\section{INTRODUCTION}

The family Pseudonocardiaceae was described by Embley et al. (1988), and the description was emended by Stackebrandt et al. (1997) on the basis of 16S rRNA gene sequence analysis. As recognized by Stackebrandt et al. (1997), the genera Actinosynnema, Saccharothrix and Streptoalloteichus

†These authors contributed equally to this work.

Abbreviations: ML, maximum-likelihood; MP, maximum-parsimony; NJ, neighbour-joining.

The GenBank/EMBL/DDBJ accession number for the $16 \mathrm{~S}$ rRNA gene sequence of strain RA45 ${ }^{\top}$ is FJ526746. were included in the family. Later studies by Labeda (1998) and Labeda \& Kroppenstedt (2000) suggested that the genera Actinokineospora, Actiosynnema, Lentzea and Saccharothrix should be assigned to a putative new taxon, the family Actinosynnemataceae. The genera Kutzneria and Streptoalloteichus might also belong to this group, according to the 16S rRNA gene sequence data given by Kim \& Goodfellow (1999). At the beginning of 2009, the family Pseudonocardiaceae included 15 genera with validly published names: Actinoalloteichus (Tamura et al., 2000), Actinomycetospora (Jiang et al., 2008), Allokutzneria (Labeda \& Kroppenstedt, 2008), Amycolatopsis (Lechevalier et al., 1986), Crossiella (Labeda, 2001), Goodfellowiella 
(Labeda et al., 2008) (previous illegitimate name Goodfellowia Labeda and Kroppenstedt 2006), Kibdelosporangium (Shearer et al., 1986), Kutzneria (Stackebrandt et al., 1994), Prauserella (Kim \& Goodfellow, 1999), Pseudonocardia (Henssen, 1957), Saccharomonospora (Nonomura \& Ohara, 1971), Saccharopolyspora (Lacey \& Goodfellow, 1975), Sciscionella (Tian et al. 2009), Streptoalloteichus (Tomita et al., 1978) and Thermocrispum (Korn-Wendisch et al., 1995). Recently, Zhi et al. (2009) proposed a new suborder Actinopolysporineae and family Actinopolysporaceae to accommodate the genus Actinopolyspora and assigned the genus Thermobispora to the suborder Streptosporangineae, although the family-level affiliation of the latter genus remains uncertain. However, the family Pseudonocardiaceae remains more diverse and loosely grouped than its sister family Actinosynnemataceae, with its characteristics including the absence of mycolic acids, the presence of an $\mathrm{N}$-acetylated type of muramic acid, cell-wall type IV or III, phospholipids of type II or III (type IV for Crossiella only; Labeda, 2001) and MK-9 $\left(\mathrm{H}_{4}\right)$ or MK-8 $\left(\mathrm{H}_{4}\right)$ as the major menaquinone.

To allow rapid exploration of the biodiversity of the family Pseudonocardiaceae, genus-specific $16 \mathrm{~S}$ rRNA gene primers have been designed for one-step identification of members of the genera Amycolatopsis (Tan et al., 2006; McVeigh et al., 1994), Saccharomonospora (Salazar et al., 2000), Saccharopolyspora and Pseudonocardia (Morón et al., 1999). The utility of genus-specific primers is defined by both their specificity and their coverage. These properties are influenced directly by the quality and quantity of sequences used to design the primers (Stach et al., 2003). So, newly sequenced 16S rRNA genes of related taxa serve as a check to evaluate primers, as well as to evaluate the latest taxonomic system.

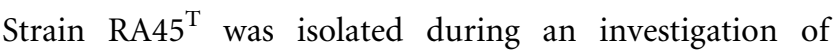
actinomycete diversity in soil from a desert region in Xinjiang Uigur Autonomous Region, north-western China. In this paper, we report the characterization and classification of strain RA45 ${ }^{\mathrm{T}}$ and propose a novel genus and species of the suborder Pseudonocardineae to accommodate it.

\section{METHODS}

Organisms and culture conditions. Strain $\mathrm{RA} 45^{\mathrm{T}}$ was isolated during the course of a study on the microbial diversity in soil samples from different biotopes from a barren desert region. Sampling and isolation were carried out in 2007 , and samples were stored at $4{ }^{\circ} \mathrm{C}$. Strain $\mathrm{RA} 45^{\mathrm{T}}$ was isolated through a serial dilution plate technique after 2 weeks of incubation at $28{ }^{\circ} \mathrm{C}$ on Sauton's agar (10 g tryptone, $2 \mathrm{~g}$ yeast extract, $10 \mathrm{~g}$ glucose, $6 \mathrm{~g} \mathrm{NaCl}, 2 \mathrm{~g}$ acid-hydrolysed casein, $1000 \mathrm{ml}$ distilled water, $\mathrm{pH}$ 7.0). To inhibit fungal growth, cycloheximide and nystatin $\left(50 \mu \mathrm{g} \mathrm{ml}^{-1}\right.$ each) were added to all media.

Morphology. Cultural characteristics of the strain were determined after growth at 28,37 and $45{ }^{\circ} \mathrm{C}$ for 2 weeks by methods used in the International Streptomyces Project (ISP) (Shirling \& Gottlieb, 1966) as well as by using Gause's asparagine agar (Gause et al., 1983) and Bennett's agar (Jones, 1949). Colour determination was performed with colour chips from the ISCC-NBS Color Charts Standard Samples no. 2106 (Kelly, 1964). Morphological observations of spore chains and mycelium were made by light microscopy (Olympus BH-2) and scanning electron microscopy (Quanta 200 FEG) after 7 days of incubation at $45{ }^{\circ} \mathrm{C}$. Gram staining (Hucker, 1921) and ZiehlNeelsen preparations (Gordon, 1967) were evaluated by light microscopy.

PCR amplification using genus-specific primers. 16S rRNA gene primers AMY2 (Tan et al., 2006) and ATOP (McVeigh et al., 1994) specific for the genus Amycolatopsis were employed in this study to screen soil samples and to test the genus-specificity of these primers. Genomic DNA extraction, PCR amplification and electrophoresis were performed as described by Tan et al. (2006).

PCR amplification of the 16S rRNA gene and sequence analysis. Genomic DNA extraction, PCR amplification and sequencing of the $16 \mathrm{~S}$ rRNA gene of strain RA $45^{\mathrm{T}}$ were carried out according to the procedures described by $\mathrm{Xu}$ et al. (2003).

Phylogenetic analysis. The $16 \mathrm{~S}$ rRNA gene sequence of strain

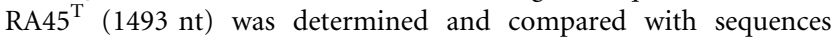
downloaded from the DDBJ, EMBL and GenBank databases. For initial taxonomic classification, a combination of BLAST search (Altschul et al., 1997; http://www.ncbi.nlm.nih.gov/blast) and the classifier program of the Ribosomal Database Project II (http://rdp. cme.msu.edu/index.jsp) was used. For phylogenetic analysis, sequences of the type strain of the type species of the type genus of each recognized suborder belonging to the phylum Actinobacteria (and some other sequences commonly used by taxonomists) were selected as the outgroup and, in a second step, sequences from the type species of all recognized genera (including Actinopolyspora and Thermobispora) in the family Pseudonocardiaceae and representatives of all six recognized genera in the sister family Actinosynnemataceae were used. Sequences shorter than $1300 \mathrm{bp}$ or which contained ambiguous nucleotides were excluded. A similarity matrix of all $16 \mathrm{~S}$ rRNA gene sequences was generated after multiple alignments of the data by CLUSTAL_X (Thompson et al., 1997). Representative sequences were chosen to make a small and robust phylogenetic dendrogram with high bootstrap values at each node. Three tree construction methods were employed in this study. Neighbour-joining (NJ) trees (Saitou \& Nei, 1987) were calculated by using distances corrected according to Kimura's two-parameter model (Kimura, 1980, 1983), with the software package TREECONW version $1.3 \mathrm{~b}$ (Van de Peer \& De Wachter, 1994, 1997). For construction of the maximum-parsimony (MP) tree, the software package MEGA version 4.0 (Tamura et al., 2007) was used. For construction of the maximum-likelihood (ML) tree, the online version of PhyML (Guindon et al., 2005) was used. The topologies of the trees were evaluated by performing a bootstrap analysis (Felsenstein, 1985) of 1000 resamplings for the NJ and MP trees and 500 resamplings for the ML tree. The root position of the tree based on the NJ method was estimated by using 28 outgroup organisms, Escherichia coli (unknown strain; GenBank accession no. J01695), Bacillus subtilis W168 (K00637), Acidimicrobium ferrooxidans $\mathrm{ICP}^{\mathrm{T}}$ (AFU75647), Coriobacterium glomerans $\mathrm{PW}^{\mathrm{T}}$ (X79048), Rubrobacter radiotolerans DSM $5868^{\mathrm{T}}$ (X98372), Bifidobacterium bifidum KCTC $3202^{\mathrm{T}}$ (BBU25951), Actinomyces bovis NCTC $11535^{\mathrm{T}}$ (X81061), Actinopolyspora halophila ATCC 27976 ${ }^{\mathrm{T}}$ (X54287), Catenulispora acidiphila DSM $44928^{\mathrm{T}}$ (AJ865857), Corynebacterium diphtheriae NCTC $11397^{\mathrm{T}}$ (X84248), Frankia alni ACN14a (NC_008278), Glycomyces harbinensis IFO $14487^{\mathrm{T}}$ (D85483), Kineosporia aurantiaca NRRL B-16913 ${ }^{\mathrm{T}}$ (AF095336), Micrococcus luteus DSM $20030^{\mathrm{T}}$ (AJ536198), Propionibacterium freudenreichii DSM $20271^{\mathrm{T}}$ (X53217), Streptosporangium roseum DSM $43021^{\mathrm{T}}$ (X89947), Micromonospora chalcea DSM $43026^{\mathrm{T}}$ (X92594), Streptomyces albus DSM $40313^{\mathrm{T}}$ (AJ621602), Streptomyces ambofaciens ATCC $23877^{\mathrm{T}}$ (M27245), Streptomyces griseus NBRC $15744^{\mathrm{T}} \quad$ (AB184699), Atopobium minutum NCFB $2751^{\mathrm{T}}$ (X67148), Arthrobacter globiformis DSM $20124^{\mathrm{T}}(\mathrm{M} 23411)$, Microbacterium lacticum IFO $14135^{\mathrm{T}}$ 
(AB007415), Sporichthya polymorpha IFO $12702^{\mathrm{T}}$ (AB025317), Nocardioides albus DSM 43109 ${ }^{\mathrm{T}}$ (X53211), Mycobacterium tuberculosis H37 (AJ536031), Sciscionella marina SCSIO 00231 ${ }^{\mathrm{T}}$ (EU503139) and Thermobispora bispora ATCC $19993^{\mathrm{T}}$ (MBU58523), as described by Labeda \& Kroppenstedt (2000) and Zhi et al. (2009).

Signature nucleotide analysis. Two sets of selected 16S rRNA gene signature nucleotides defined for the suborder Pseudonocardineae (Stackebrandt et al., 1997; Zhi et al., 2009) were checked in this study using methods described by Zhi et al. (2009).

Isolation of DNA and determination of the $\mathbf{G}+\mathbf{C}$ content. Cell material for genomic DNA extraction was obtained after cultivation at $28{ }^{\circ} \mathrm{C}$ for 4 days in ISP 2 broth (Shirling \& Gottlieb, 1966) as a shaking culture. Chromosomal DNA for genomic DNA G + C content analysis was extracted as described by Marmur (1961). The DNA $\mathrm{G}+\mathrm{C}$ content was determined by thermal denaturation (Mandel \& Marmur, 1968).

Determination of physiological characteristics. Growth was tested at $4,10,28,37,45$ and $50{ }^{\circ} \mathrm{C}$ on modified Bennett's agar (Jones, 1949). The ability of strain RA45 ${ }^{\mathrm{T}}$ to grow was determined at $\mathrm{pH} 4.0-12.0$ on ISP 2 medium, adjusted to the appropriate $\mathrm{pH}$ using $0.1 \mathrm{M}$ solutions of potassium dihydrogen phosphate and dipotassium hydrogen phosphate (Sambrook \& Russell, 2001). After incubation for up to 21 days, growth was scored as a positive result. Tolerance of $\mathrm{NaCl}$ was examined at $0-10 \%(\mathrm{w} / \mathrm{v})$ on ISP 2 agar. Physiological tests including degradation of adenine, hypoxanthine, xanthine, L-tyrosine, xylan, uric acid, allantoin and urea were conducted as described previously (Kumar \& Goodfellow, 2008).

Analysis of chemotaxonomic characteristics. Cell material for chemotaxonomic studies was obtained after cultivation at $28{ }^{\circ} \mathrm{C}$ for 7-10 days in ISP 2 broth (Shirling \& Gottlieb, 1966) as a shaking culture. Extraction and analysis of mycolic acids followed the method described by Hamid et al. (1993). Determination of the $\mathrm{N}$-acyl type of muramic acid residues followed the procedure described by Uchida et al. (1999). Procedures for analysis of diagnostic cell-wall amino acids and sugars followed those described by Staneck \& Roberts (1974). Polar lipids were extracted, examined by two-dimensional TLC and identified using the procedures of Minnikin et al. (1984). Menaquinones were extracted according to Minnikin et al. (1984) and separated by HPLC (Kroppenstedt, 1982). The cellular fatty acid composition was determined as described by Sasser (1990) using the Microbial Identification System (MIDI, Inc.), and the results were compared with the database of fatty acids in the Microbial Identification System.

\section{RESULTS AND DISCUSSION}

A database search based on the 16S rRNA gene sequence demonstrated that strain RA45 ${ }^{\mathrm{T}}$ belongs to the family Pseudonocardiaceae (Stackebrandt et al., 1997; Zhi et al., 2009). A phylogenetic study was performed with 16 S rRNA gene sequences of type strains of the type species of all genera with validly published names in the family Pseudonocardiaceae and the sister family Actinosynnemataceae (Labeda \& Kroppenstedt, 2000). According to the similarity matrix based on the alignment of all cited representative $16 \mathrm{~S}$ rRNA gene sequences, the closest relatives of strain RA45 ${ }^{\mathrm{T}}$ were Prauserella rugosa DSM $43194^{\mathrm{T}}$, with $94.67 \%$ sequence identity, Prauserella halophila YIM $90001^{\mathrm{T}}$ (94.45\%), Amycolatopsis palatopharyngis $1 \mathrm{BDZ}^{\mathrm{T}}(94.38 \%)$, Amycolatopsis sacchari $\mathrm{K}_{2} 4^{\mathrm{T}}(94.35 \%)$, Saccharomonospora saliphila YIM $90502^{\mathrm{T}}(94.34 \%)$ and Thermocrispum municipale DSM $44069^{\mathrm{T}}(94.32 \%)$. The sequence identity to type strains belonging to other genera of the suborder Pseudonocardineae was below $94.30 \%$. The $16 \mathrm{~S}$ rRNA gene sequence similarity between members of the genus Actinopolyspora and representatives of the emended suborder Pseudonocardineae (Zhi et al., 2009) ranged from 85.89 to $90.52 \%$ and the similarity between members of the genus Thermobispora and representatives of the emended suborder Pseudonocardineae (Zhi et al., 2009) ranged from 85.91 to $88.43 \%$, supporting the decision of Zhi et al. (2009) to exclude these two genera from the suborder Pseudonocardineae.

Although the use of genus-specific primers designed for Amycolatopsis (AMY2 and ATOP) (Tan et al., 2006; McVeigh et al., 1994) showed that strain RA45 ${ }^{\mathrm{T}}$ yielded the same $\sim 440$ bp 16S rRNA gene fragment as members of the genus Amycolatopsis, as shown by the consensus phylogenetic tree (Fig. 1), strain RA $45^{\mathrm{T}}$ always formed a subclade distinct from the phylogenetic radiation formed by the genera Prauserella, Amycolatopsis, Thermocrispum, Saccharomonospora and Saccharopolyspora, adjacent to the Thermocrispum clade. However, the separate branching of strain $\mathrm{RA}^{\mathrm{T}} \mathrm{T}^{\mathrm{T}}$ was supported by bootstrap values below $50 \%$. Furthermore, the whole-suborder phylogenetic tree was consistently divided into two large, approximately symmetrical clusters with high bootstrap values $(>70 \%)$, and the family Actinosynnemataceae formed a subclade that fell into one of the large clusters, while RA $45^{\mathrm{T}}$ fell into the other, as discussed above. Interestingly, the Sciscionella, Pseudonocardia and Actinomycetospora sequences formed three long, deep branches into the two large radiations.

Analysis of the patterns of signature nucleotides also supported our conclusions given above. Signature nucleotides of the 16S rRNA gene sequence of strain RA $45^{\mathrm{T}}$ were shared in all positions (according to the Escherichia coli numbering scheme) with the pattern of signature nucleotides reported for the suborder Pseudonocardineae described by Zhi et al. (2009) (Table 1). However, for the $16 \mathrm{~S}$ rRNA signatures of the families Pseudonocardiaceae and Actinosynnemataceae at positions 211, 480 and $142: 221$, our observations differed from those of Zhi et al. (2009). There were no differences between the two families at these positions, with members of the two families sharing A at position $211, \mathrm{U}$ at position 480 and C-C at positions $142: 221$, with only two exceptions, Sciscionella marina SCSIO $00231^{\mathrm{T}}$ and our isolate RA45 ${ }^{\mathrm{T}}$, which both carried $\mathrm{U}$ at position 221 .

Strain RA $45^{\mathrm{T}}$ could also be distinguished from all other representatives of the suborder Pseudonocardineae (Zhi et al., 2009) by a combination of morphological and chemical characteristics (Table 2). Growth of strain RA $45^{\mathrm{T}}$ was good on most media tested, especially on yeast extract-malt extract (ISP 2) agar, and the optimal growth temperature was $37-45{ }^{\circ} \mathrm{C}$. Soluble brown pigments were produced at 37 


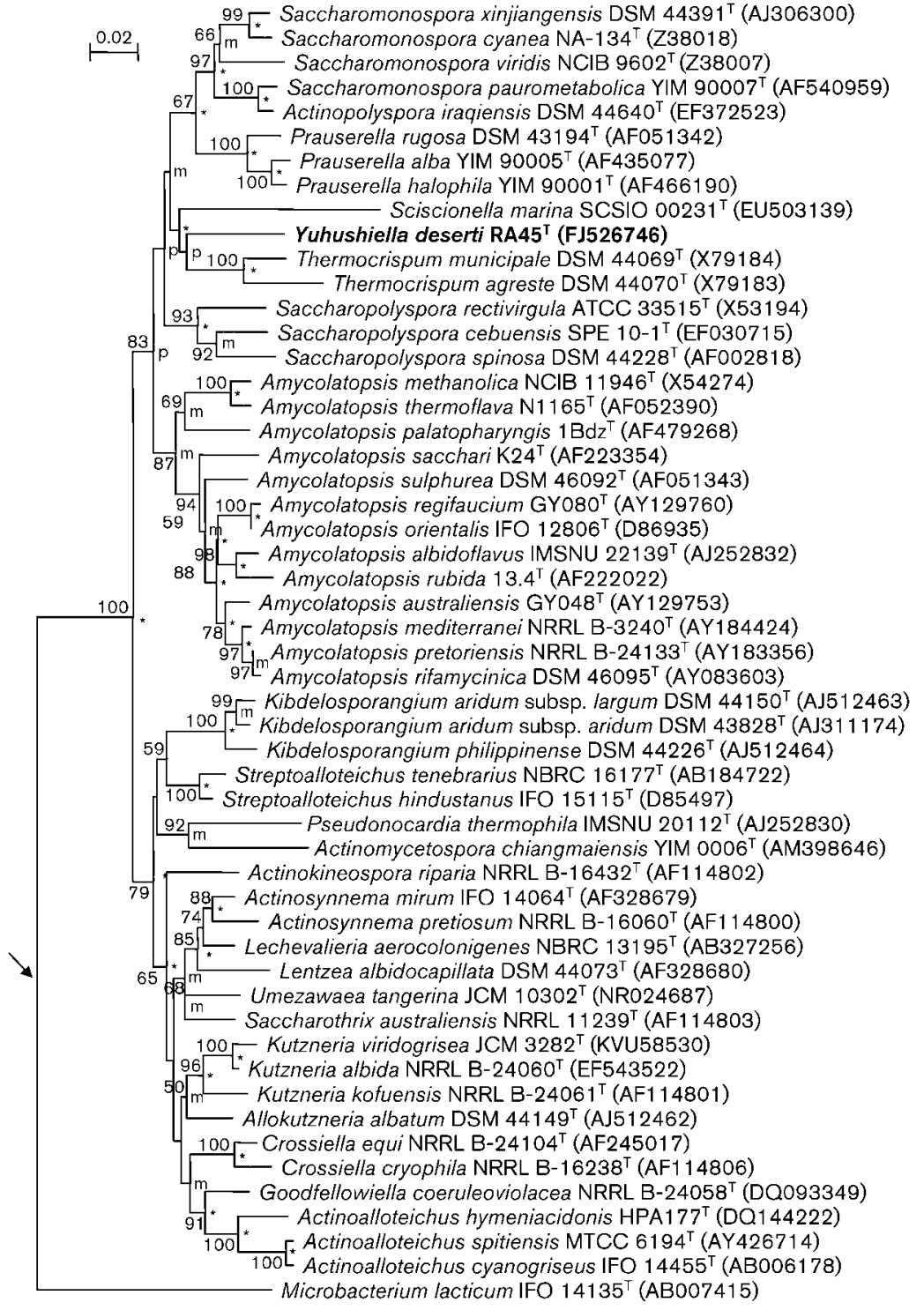

Fig. 1. NJ tree derived from $16 \mathrm{~S}$ rRNA gene sequences showing the relationship between strain $\mathrm{RA}^{\mathrm{T}} 5^{\mathrm{T}}$ and representatives of the suborder Pseudonocardineae. Asterisks indicate branches recovered with all three methods; $\mathrm{m}$ and $\mathrm{p}$ indicate branches that were also recovered by using the ML (Felsenstein, 1981) and MP (Fitch, 1971) treeing algorithms, respectively. Numbers at nodes indicate levels of bootstrap support based on an NJ (Saitou \& Nei, 1987) analysis of 1000 resampled datasets; only values above $50 \%$ are given. The arrow indicates the estimated position of the ten remaining root organisms (see Methods for details). Bar, 0.02 substitutions per nucleotide position. and $45{ }^{\circ} \mathrm{C}$ on Bennett's agar, but were absent at other temperatures. No aerial mycelium was observed under any of the culture conditions used in this study. The hyphae $(0.2 \mu \mathrm{m}$ in diameter $)$ which covered the surfaces of colonies were straight to flexuous, smooth and branched (Fig. 2) and were pale yellow to light yellow. The vegetative hyphae frequently formed aggregates and globose or irregularformed sporangium-like structures $(5-10 \mu \mathrm{m})$ with irregular surfaces (Fig. 2), which differed from those formed by Kibdelosporangium strains and the 'pseudosporangia' of Thermocrispum and Crossiella strains. Sessile global swellings $(0.2-0.3 \mu \mathrm{m})$ were found consistently, especially at the ends of the aerial mycelium. Fragmentation seldom occurred in the substrate mycelium. Motile spores were not detected despite extensive observation.

Strain RA45 ${ }^{\mathrm{T}}$ lacked mycolic acids and contained muramic acid in the $N$-acetylated form, which is consistent with the properties of other genera of the family Pseudono- cardiaceae. The cell wall of strain $\mathrm{RA} 45^{\mathrm{T}}$ contained meso-diaminopimelic acid as the diagnostic peptidoglycan diamino acid. Whole-cell hydrolysates contained ribose, arabinose, glucose and galactose as diagnostic sugars (cellwall chemotype IV; Lechevalier \& Lechevalier, 1970). Analysis of phospholipids revealed that phosphatidylethanolamine, phosphatidylinositol mannosides, phosphatidylmethylethanolamine, diphosphatidylglycerol, phospholipids of unknown structure and glucosamine-containing phospholipids of unknown structure were the major phospholipids, indicating phospholipid type IV (Lechevalier et al., 1977). The predominant menaquinone was MK$9\left(\mathrm{H}_{4}\right)(66.12 \%)$, and minor amounts of MK-9 (12.69\%), MK-9 $\left(\mathrm{H}_{2}\right) \quad(9.08 \%), \quad \mathrm{MK}-10\left(\mathrm{H}_{2}\right) \quad(3.52 \%), \quad \mathrm{MK}-8\left(\mathrm{H}_{2}\right)$ $(2.10 \%)$ and $\mathrm{MK}-8(0.59 \%)$ were detected. The fatty acid profile consisted of the predominant component isobranched hexadecanoic acid (iso- $\mathrm{C}_{16: 0} ; 24.41 \%$ ) and smaller amounts of $\mathrm{C}_{14: 0}(2.04 \%)$, iso- $\mathrm{C}_{15: 1}(1.61 \%)$, iso- $\mathrm{C}_{16: 1}(2.66 \%), \mathrm{C}_{16: 1} \omega 7 c /$ iso- $\mathrm{C}_{15: 0} \quad 2-\mathrm{OH} \quad(9.96 \%)$, 
Table 1. Signature nucleotides of the 16S rRNA sequences of members of the family Pseudonocardiaceae

Data were analysed in this study unless indicated, from the type strain of the type species of each genus. For the family Pseudonocardiaceae, 'other genera' represents Amycolatopsis, Prauserella, Saccharomonospora, Saccharopolyspora, Actinomycetospora, Pseudonocardia, Crossiella, Actinoalloteichus, Goodfellowiella, Allokutzneria, Kutzneria, Kibdelosporangium and Streptoalloteichus. For the family Actinosynnemataceae, the genera included were Actinokineospora, Umezawaea, Saccharothrix, Lentzea, Lechevalieria and Actinosynnema. Positions are given relative to the Escherichia coli numbering scheme. Y, Pyrimidine. Signatures specific for the suborder Pseudonocardineae and for the families Pseudonocardiaceae and Actinosynnemataceae are listed. Signatures that differ from those given by Zhi et al. (2009) are highlighted in bold.

\begin{tabular}{|c|c|c|c|c|c|c|c|}
\hline \multirow[t]{2}{*}{ Position(s) } & \multicolumn{5}{|c|}{ Pseudonocardiaceae } & \multicolumn{2}{|c|}{ Actinosynnemataceae } \\
\hline & Zhi et al. (2009) & \multicolumn{4}{|c|}{ Our study } & $\begin{array}{c}\text { Zhi et al. } \\
\quad(2009)\end{array}$ & Our study \\
\hline \multicolumn{8}{|l|}{ Suborder } \\
\hline \multicolumn{8}{|c|}{ Pseudonocardineae } \\
\hline $672: 734$ & $\mathrm{U}-\mathrm{G}$ & $\mathrm{U}-\mathrm{G}$ & $\mathrm{U}-\mathrm{G}$ & $\mathrm{U}-\mathrm{G}$ & $\mathrm{U}-\mathrm{G}$ & $\mathrm{U}-\mathrm{G}$ & $\mathrm{U}-\mathrm{G}$ \\
\hline $831: 855$ & $\mathrm{U}-\mathrm{G}$ & $\mathrm{U}-\mathrm{G}$ & $\mathrm{U}-\mathrm{G}$ & $\mathrm{U}-\mathrm{G}$ & $\mathrm{U}-\mathrm{G}$ & $\mathrm{U}-\mathrm{G}$ & $\mathrm{U}-\mathrm{G}$ \\
\hline $832: 854$ & $\mathrm{G}-\mathrm{Y}$ & $\mathrm{G}-\mathrm{U}$ & $\mathrm{G}-\mathrm{U}$ & $\mathrm{G}-\mathrm{U}$ & $\mathrm{G}-\mathrm{U}$ & $\mathrm{G}-\mathrm{U}$ & $\mathrm{G}-\mathrm{U}$ \\
\hline $833: 853$ & $\mathrm{U}-\mathrm{G}$ & $U-G$ & $\mathrm{U}-\mathrm{G}$ & $\mathrm{U}-\mathrm{G}$ & $\mathrm{U}-\mathrm{G}$ & $\mathrm{U}-\mathrm{G}$ & $\mathrm{U}-\mathrm{G}$ \\
\hline $952: 1229$ & $\mathrm{U}-\mathrm{A}$ & $\mathrm{U}-\mathrm{A}$ & $\mathrm{U}-\mathrm{A}$ & $\mathrm{U}-\mathrm{A}$ & $\mathrm{U}-\mathrm{A}$ & $\mathrm{U}-\mathrm{A}$ & $\mathrm{U}-\mathrm{A}$ \\
\hline 211 & G & A & A & $\mathbf{A}$ & A & $\mathrm{A}$ & $\mathrm{A}$ \\
\hline 480 & $\mathrm{U}$ & $\mathrm{U}$ & $\mathrm{U}$ & $\mathrm{U}$ & $\mathrm{U}$ & G & $\mathbf{U}$ \\
\hline $142: 221$ & $\mathrm{C}-\mathrm{G}$ & $\mathrm{C}-\mathbf{U}$ & $\mathrm{C}-\mathrm{C}$ & $\mathrm{C}-\mathbf{U}$ & $\mathrm{C}-\mathrm{C}$ & $\mathrm{C}-\mathrm{C}$ & $\mathrm{C}-\mathrm{C}$ \\
\hline
\end{tabular}

$\mathrm{C}_{16: 0} \quad(7.55 \%), \quad 10$-methyl $\mathrm{C}_{16: 0} \quad(2.12 \%)$, iso- $\mathrm{C}_{17: 0}$ (3.54\%), anteiso- $\mathrm{C}_{17: 0} \quad(6.04 \%), \quad \mathrm{C}_{17: 1} \omega 8 c \quad(3.50 \%)$, $\mathrm{C}_{17: 1} \omega 6 c(11.37 \%), \mathrm{C}_{17: 0}(1.25 \%), \quad 10$-methyl $\mathrm{C}_{17: 0}$ $(1.53 \%), \quad$ iso- $\mathrm{C}_{18: 0} \quad(2.60 \%), \mathrm{C}_{18: 1} \omega 9 c \quad(4.24 \%)$, $\mathrm{C}_{18: 1} \omega 7 c(1.06 \%)$ and $\mathrm{C}_{18: 0}(8.48 \%)$. The $\mathrm{G}+\mathrm{C}$ content of the genomic DNA of the strain was $69.9 \mathrm{~mol} \%$.

On the basis of a combination of phylogenetic distinctness and differences in morphological and chemotaxonomic features, we consider that strain $\mathrm{RA} 45^{\mathrm{T}}$ represents a novel genus and species, for which the name Yuhushiella deserti gen. nov., sp. nov. is proposed.

\section{Description of Yuhushiella gen. nov.}

Yuhushiella (Yu.hu.shi.el'la. N.L. dim. ending -ella; N.L. fem. n. Yuhushiella named after Professor Yuhu Shi, a Chinese microbiologist, in recognition of his leadership and contributions to the exploration of the microbial resources of Xinjiang Uigur Autonomous Region, China).

Aerobic, Gram-stain-positive, non-acid-fast, non-motile actinomycetes. Vegetative mycelium is straight to flexuous, smooth and branched. Swelling and aggregation of the hyphae occur, but fragmentation is seldom observed. The cell wall contains meso-diaminopimelic acid. Whole-cell hydrolysates contain ribose, arabinose, glucose and galac- tose (cell-wall chemotype IV). Diphosphatidylglycerol, phosphatidylethanolamine, phosphatidylmethylethanolamine, phosphatidylinositol mannosides, phospholipids of unknown structure and glucosamine-containing phospholipids of unknown structure are the diagnostic phospholipids. Mycolic acids are absent and $N$-acetylated-type muramic acid is present. The predominant menaquinone is MK-9 $\left(\mathrm{H}_{4}\right)$. The genus is a member of the family Pseudonocardiaceae in the suborder Pseudonocardineae. The type species is Yuhushiella deserti.

\section{Description of Yuhushiella deserti sp. nov.}

Yuhushiella deserti (de.ser'ti. L. gen. n. deserti of a desert).

In addition to the characteristics given in the genus description, the species has the following properties. Vegetative mycelium is pale yellow to light yellow. Two types of sporangia are observed: swellings $(0.5-2 \mu \mathrm{m})$ are formed at the ends or branch joints of the mycelium and 'post-pseudosporangia' $(5-10 \mu \mathrm{m})$ are formed from mycelial aggregation and merging (Fig. 2). The 'post-pseudosporangia', similar to the pseudosporangia of Thermocrispum and Crossiella strains, are not surrounded by a welldefined wall and contain hyphae that fragment into rod-like structures, but the hyphae are not totally septate. A brown 
Table 2. Diagnostic characteristics of strain RA45 ${ }^{\top}$ and phylogenetically closely related genera in the suborder Pseudonocardineae

Data for reference genera were taken from Lechevalier et al. (1986), Kim \& Goodfellow (1999), Li et al. (2003a, b), Bian et al. (2009), Chun et al. (1999), Goodfellow et al. (2001), Huang et al. (2004), Kim et al. (2002), Tseng et al. (2006), Al-Zarban et al. (2002), Dolashka et al. (1998), Jin et al. (1998), Syed et al. (2008), Yoon et al. (2000), Lu et al. (2001), Pimentel-Elardo et al. (2008), Qin et al. (2008), Zhang et al., (2008) and KornWendisch et al. $(1989,1995)$. None of the genera show acropetal budding (primordial reproduction on hyphal tips). Only Amycolatopsis taiwanensis shows formation of bud-like structures on substrate hyphae (primordial hyphal differentiation). +, Present or positive; - , absent or negative; ND, not detected (may be no sporal differentiation); NA, not applicable (no aerial hyphae).

\begin{tabular}{|c|c|c|c|c|c|c|c|}
\hline Characteristic & Strain RA45 ${ }^{\mathrm{T}}$ & Thermocrispum & Amycolatopsis & Prauserella & Saccharomonospora & Saccharopolyspora & Sciscionella \\
\hline $\begin{array}{l}\text { Aerial hyphae } \\
\text { (hyphal } \\
\text { differentiation) }\end{array}$ & - & + & $+^{*}$ & $\begin{array}{l}+(\text { except } P . \\
\text { rugosa })\end{array}$ & + & + & Sparse \\
\hline \multicolumn{8}{|l|}{ Substrate hyphae } \\
\hline Fragmentation & Seldom & + & + & + & - & + & + \\
\hline Spores $\dagger$ & - & - & $\begin{array}{l}\text { Primordial } \\
\text { spore chains } \\
\text { from hyphal } \\
\text { fragmentation }\end{array}$ & - & $\begin{array}{l}\text { Petiolate spores } \\
\text { singly or in } \\
\text { longitudinal pairs }\end{array}$ & $\begin{array}{l}\text { From hyphal } \\
\text { fragmentation }\end{array}$ & - \\
\hline $\begin{array}{l}\text { Sporangium-like } \\
\text { structures }\end{array}$ & + & $\begin{array}{c}\text { Pseudosporangia } \\
\text { (hyphal } \\
\text { aggregates) }\end{array}$ & - & - & - & - & - \\
\hline \multicolumn{8}{|l|}{ Aerial hyphae } \\
\hline Fragmentation & NA & $\begin{array}{l}+ \text { (into rod- } \\
\text { like structures) }\end{array}$ & + & - & - & + & - \\
\hline Spores $\dagger$ & $\mathrm{NA}$ & $\mathrm{ND}$ & $\begin{array}{c}\text { Primordial } \\
\text { spore chains } \\
\text { from hyphal } \\
\text { fragmentation }{ }^{\star} \ddagger\end{array}$ & $\begin{array}{c}\text { Well- } \\
\text { developed, } \\
\text { long, } \\
\text { branched } \\
\text { spore chains }\end{array}$ & $\begin{array}{l}\text { Petiolate spores, } \\
\text { singly or in } \\
\text { longitudinal pairs }\end{array}$ & $\begin{array}{c}\text { In chains (from } \\
\text { hyphal } \\
\text { segregation) }\end{array}$ & - \\
\hline $\begin{array}{l}\text { Sporangium-like } \\
\text { structures }\end{array}$ & $\mathrm{NA}$ & $\begin{array}{c}\text { Pseudo- } \\
\text { sporangia (hyphal } \\
\text { aggregates) }\end{array}$ & - & - & - & - & - \\
\hline \multicolumn{8}{|l|}{$\begin{array}{l}\text { Chemical } \\
\text { properties }\end{array}$} \\
\hline Phospholipid type $\$$ & IV & II & II & II & II & III & III \\
\hline Sugar patternll & $\begin{array}{l}\text { Ara, Gal, } \\
\text { Glc, Rib }\end{array}$ & $\begin{array}{l}\text { Ara, Man, } \\
\text { Glc, (Gal) }\end{array}$ & Ara, Gal & Ara, Gal & Ara, Gal & Ara, Gal & Ara, Gal, Glc \\
\hline $\begin{array}{l}\text { Predominant } \\
\text { menaquinone }(\mathrm{s}) \mathrm{g}\end{array}$ & $9\left(\mathrm{H}_{4}\right)$ & $9\left(\mathrm{H}_{4}\right)$ & $9\left(\mathrm{H}_{2}, \mathrm{H}_{4}, \mathrm{H}_{6}\right)$ & $9\left(\mathrm{H}_{2}, \mathrm{H}_{4}\right)$ & $8\left(\mathrm{H}_{4}\right), 9\left(\mathrm{H}_{4}\right)$ & $9\left(\mathrm{H}_{4}\right), 10\left(\mathrm{H}_{4}\right)$ & $9\left(\mathrm{H}_{4}\right)$ \\
\hline $\begin{array}{l}\text { DNA G }+\mathrm{C} \text { content } \\
(\mathrm{mol} \%)\end{array}$ & 69.9 & $69-73$ & $66-73$ & $65.8-69.9$ & $66-74$ & $70-77$ & 69 \\
\hline
\end{tabular}

${ }^{\star}$ Except Amycolatopsis taiwanensis.

$\dagger$ Refers to the presence of sporal differentiation, motile spores, conidiospores, etc.

$\ddagger A$. taiwanensis forms bud-like structures separated from the substrate hyphae.

\$II, Phosphatidylethanolamine; III, phosphatidylcholine (with phosphatidylethanolamine, phosphatidylmethylethanolamine and phosphatidylglycerol variable; no phospholipids containing glucosamine); IV, phospholipids containing glucosamine, phosphatidylethanolamine variable, phosphatidylmethylethanolamine variable, no phosphatidylglycerol, no phosphatidylcholine (Lechevalier et al., 1977).

IIAra, Arabinose; Gal, galactose; Glc, glucose; Man, mannose; Rib, ribose. Compounds in parentheses are present in trace amounts.

SAbbreviations are exemplified by $9\left(\mathrm{H}_{4}\right)$, menaquinones with four of the nine isoprene units hydrogenated.

soluble pigment is produced during cultivation at $37-45{ }^{\circ} \mathrm{C}$. Grows well on all tested media; optimal culture conditions are $37-45{ }^{\circ} \mathrm{C}$, pH 9.0 and $3.5 \%$ (w/v) $\mathrm{NaCl}$. Casein, starch, L-tyrosine, uric acid and urea are hydrolysed or decomposed. Adenine, allantoin, xylan, hypoxanthine and xanthine are not hydrolysed or decomposed. The major cellular fatty acids are iso- $\mathrm{C}_{16: 0}, \mathrm{C}_{16: 1} \omega 7 c /$ iso- $\mathrm{C}_{15: 0} 2-\mathrm{OH}$,
$\mathrm{C}_{16: 0}$, anteiso- $\mathrm{C}_{17: 0}, \mathrm{C}_{17: 1} \omega 6 c$ and $\mathrm{C}_{18: 0}$. The DNA G+C content of the type strain is $69.9 \mathrm{~mol} \%$.

The type strain, RA45 ${ }^{\mathrm{T}}$ (=CGMCC $4.5579^{\mathrm{T}}=\mathrm{JCM}$ $16584^{\mathrm{T}}$ ), was isolated from soil collected from a desert region in Xinjiang Uigur Autonomous Region, northwestern China. 

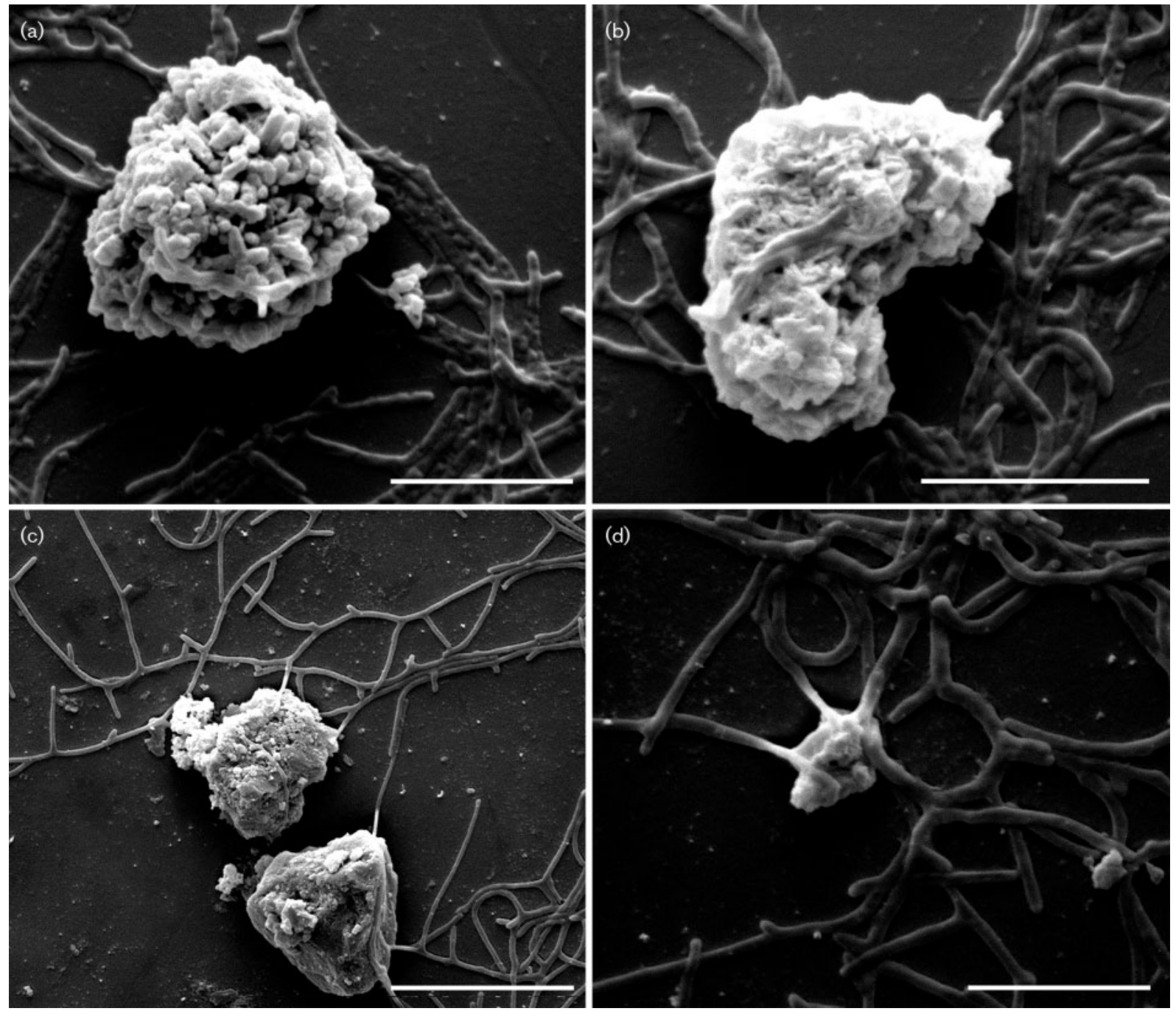

Fig. 2. Scanning electron micrographs of 'post-pseudosporangia' of a 7-day-old coverslip culture of strain $\mathrm{RA}^{\mathrm{T}} 5^{\top}$ grown on Gause's asparagine agar at $45^{\circ} \mathrm{C}$. Bars, $5.0 \mu \mathrm{m}(\mathrm{a}, \mathrm{b}, \mathrm{d})$ and $10.0 \mu \mathrm{m}$ (c).

\section{ACKNOWLEDGEMENTS}

The authors are very grateful to Dr J. P. Euzéby for his advice on nomenclature and thank Professor Dong Han and Ms Jia-Yi Xie for technical assistance. This work was kindly supported in part by grants from the Hi-Tech Research and Development Program of China (grant no. 2007AA021300), 'Application of Nuclear Techniques in Agriculture' from the Chinese Ministry of Agriculture (no. 200803034), the National Natural Science Foundation of China (no. 30700015), the National 863 Project (nos 2006AA09Z402 and 2007AA09Z443) and the Chinese Academy of Sciences Innovation Projects O62A131BB4. L.-X.Z. was an awardee of the Hundred Talents Program.

\section{REFERENCES}

Al-Zarban, S. S., Al-Musallam, A. A., Abbas, I., Stackebrandt, E. \& Kroppenstedt, R. M. (2002). Saccharomonospora halophila sp. nov., a novel halophilic actinomycete isolated from marsh soil in Kuwait. Int J Syst Evol Microbiol 52, 555-558.
Altschul, S. F., Madden, T. L., Schäffer, A. A., Zhang, J., Zhang, Z., Miller, W. \& Lipman, D. J. (1997). Gapped BLAST and PSI-BLAST: a new generation of protein database search programs. Nucleic Acids Res 25, 3389-3402.

Bian, J., Li, Y., Wang, J., Song, F. H., Liu, M., Dai, H. Q., Ren, B., Gao, H., Hu, X. \& other authors (2009). Amycolatopsis marina sp. nov., an actinomycete isolated from an ocean sediment. Int J Syst Evol Microbiol 59, 477-481.

Chun, J., Kim, S. B., Oh, Y. K., Seong, C. N., Lee, D. H., Bae, K. S., Lee, K. J., Kang, S. O., Hah, Y. C. \& Goodfellow, M. (1999). Amycolatopsis thermoflava sp. nov., a novel soil actinomycete from Hainan Island, China. Int J Syst Bacteriol 49, 1369-1373.

Dolashka, P., Georgieva, D. N., Stoeva, S., Genov, N., Rachev, R., Gusterova, A. \& Voelter, W. (1998). A novel thermostable neutral proteinase from Saccharomonospora canescens. Biochim Biophys Acta 1382, 207-216.

Embley, T. M., Smida, J. \& Stackebrandt, E. (1988). Reverse transcriptase sequencing of $16 \mathrm{~S}$ ribosomal RNA from Faenia rectivirgula, Pseudonocardia thermophila and Saccharopolyspora hirsuta, three wall 
type IV actinomycetes which lack mycolic acids. J Gen Microbiol 134, 961-966.

Felsenstein, J. (1981). Evolutionary trees from DNA sequences: a maximum likelihood approach. J Mol Evol 17, 368-376.

Felsenstein, J. (1985). Confidence limits on phylogenies: an approach using the bootstrap. Evolution 39, 783-791.

Fitch, W. M. (1971). Toward defining the course of evolution: minimum change for a specific tree topology. Syst Zool 20, 406-416.

Gause, G. F., Preobrazhenskaya, T. P., Sveshnikova, G. V., Terekhova, L. P. \& Maksimova, T. S. (1983). A Guide for Determination of Actinomycetes. Moscow: Nauka (in Russian).

Goodfellow, M., Kim, S. B., Minnikin, D. E., Whitehead, D., Zhou, Z. H. \& Mattinson-Rose, A. D. (2001). Amycolatopsis sacchari sp. nov., a moderately thermophilic actinomycete isolated from vegetable matter. Int J Syst Evol Microbiol 51, 187-193.

Gordon, R. E. (1967). The taxonomy of soil bacteria. In The Ecology of Soil Bacteria, pp. 293-321. Edited by T. R. G. Gray \& D. Parkinson. Liverpool: Liverpool University Press.

Guindon, S., Lethiec, F., Duroux, P. \& Gascuel, O. (2005). PHYML Online - a web server for fast maximum likelihood-based phylogenetic inference. Nucleic Acids Res 33, W557-W559.

Hamid, M. E., Minnikin, D. E., Goodfellow, M. \& Ridell, M. (1993). Thin-layer chromatographic analysis of glycolipids and mycolic acids from Mycobacterium farcinogenes, Mycobacterium senegalense and related taxa. Zentralbl Bakteriol 279, 354-367.

Henssen, A. (1957). Beiträge zur Morphologie und Systematik der thermophilen Actinomyceten. Arch Mikrobiol 26, 373-414 (in German).

Huang, Y., Paściak, M., Liu, Z., Xie, Q. \& Gamian, A. (2004). Amycolatopsis palatopharyngis sp. nov., a potentially pathogenic actinomycete isolated from a human clinical source. Int J Syst Evol Microbiol 54, 359-363.

Hucker, G. J. (1921). A new modification and application of the Gram stain. J Bacteriol 6, 395-397.

Jiang, Y., Wiese, J., Tang, S. K., Xu, L. H., Imhoff, J. F. \& Jiang, C. L. (2008). Actinomycetospora chiangmaiensis gen. nov., sp. nov., a new member of the family Pseudonocardiaceae. Int J Syst Evol Microbiol 58 $408-413$.

Jin, X., Xu, L. H., Mao, P. H., Hseu, T. H. \& Jiang, C. L. (1998). Description of Saccharomonospora xinjiangensis sp. nov. based on chemical and molecular classification. Int J Syst Bacteriol 48, 10951099.

Jones, K. L. (1949). Fresh isolates of actinomycetes in which the presence of sporogenous aerial mycelia is a fluctuating characteristic. J Bacteriol 57, 141-145.

Kelly, K. L. (1964). Inter-Society Color Council-National Bureau of Standards Color Name Charts Illustrated with Centroid Colors. Washington, DC: US Government Printing Office.

Kim, S. B. \& Goodfellow, M. (1999). Reclassification of Amycolatopsis rugosa Lechevalier et al. 1986 as Prauserella rugosa gen. nov., comb. nov. Int J Syst Bacteriol 49, 507-512.

Kim, B., Sahin, N., Tan, G. Y. A., Zakrzewska-Czerwinska, J. \& Goodfellow, M. (2002). Amycolatopsis eurytherma sp. nov., a thermophilic actinomycete isolated from soil. Int J Syst Evol Microbiol 52, 889-894.

Kimura, M. (1980). A simple method for estimating evolutionary rates of base substitutions through comparative studies of nucleotide sequences. J Mol Evol 16, 111-120.

Kimura, M. (1983). The Neutral Theory of Molecular Evolution. Cambridge: Cambridge University Press.
Korn-Wendisch, F., Kempf, A., Grund, E., Kroppenstedt, R. M. \& Kutzner, H. J. (1989). Transfer of Faenia rectivirgula Kurup and Agre 1983 to the genus Saccharopolyspora Lacey and Goodfellow 1975, elevation of Saccharopolyspora hirsuta subsp. taberi Labeda 1987 to species level, and emended description of the genus Saccharopolyspora. Int J Syst Bacteriol 39, 430-441.

Korn-Wendisch, F., Rainey, F., Kroppenstedt, R. M., Kempf, A., Majazza, A., Kutzner, H. J. \& Stackebrandt, E. (1995). Thermocrispum gen. nov., a new genus of the order Actinomycetales, and description of Thermocrispum municipale sp. nov. and Thermocrispum agreste sp. nov. Int J Syst Bacteriol 45, 67-77.

Kroppenstedt, R. M. (1982). Separation of bacterial menaquinones by HPLC using reverse phase (RP18) and a silver loaded ion exchanger as stationary phases. J Liq Chromatogr 5, 23592367.

Kumar, Y. \& Goodfellow, M. (2008). Five new members of the Streptomyces violaceusniger $16 \mathrm{~S}$ rRNA gene clade: Streptomyces castelarensis sp. nov., comb. nov., Streptomyces himastatinicus sp. nov., Streptomyces mordarskii sp. nov., Streptomyces rapamycinicus sp. nov. and Streptomyces ruanii sp. nov. Int J Syst Evol Microbiol 58, 1369-1378.

Labeda, D. P. (1998). Phylogenetic analysis of the genus Saccharothrix and related taxa. In Abstracts of the 98th General Meeting of the American Society for Microbiology, Atlanta, GA, p. 485. Washington, DC: American Society for Microbiology.

Labeda, D. P. (2001). Crossiella gen. nov., a new genus related to Streptoalloteichus. Int J Syst Evol Microbiol 51, 1575-1579.

Labeda, D. P. \& Kroppenstedt, R. M. (2000). Phylogenetic analysis of Saccharothrix and related taxa: proposal for Actinosynnemataceae fam. nov. Int J Syst Evol Microbiol 50, 331-336.

Labeda, D. P. \& Kroppenstedt, R. M. (2006). Goodfellowia gen. nov., a new genus of the Pseudonocardineae related to Actinoalloteichus, containing Goodfellowia coeruleoviolacea gen. nov., comb. nov. Int J Syst Evol Microbiol 56, 1203-1207.

Labeda, D. P. \& Kroppenstedt, R. M. (2008). Proposal for the new genus Allokutzneria gen. nov. within the suborder Pseudonocardineae and transfer of Kibdelosporangium albatum Tomita et al. 1993 as Allokutzneria albata comb. nov. Int J Syst Evol Microbiol 58, 14721475.

Labeda, D. P., Kroppenstedt, R. M., Euzéby, J. P. \& Tindall, B. J. (2008). Proposal of Goodfellowiella gen. nov. to replace the illegitimate genus name Goodfellowia Labeda and Kroppenstedt 2006. Int J Syst Evol Microbiol 58, 1047-1048.

Lacey, J. \& Goodfellow, M. (1975). A novel actinomycete from sugarcane bagasse: Saccharopolyspora hirsuta gen. et sp. nov. J Gen Microbiol 88, 75-85.

Lechevalier, M. P. \& Lechevalier, H. A. (1970). Chemical composition as a criterion in the classification of aerobic actinomycetes. Int $J$ Syst Bacteriol 20, 435-443.

Lechevalier, M. P., De Bièvre, C. \& Lechevalier, H. A. (1977). Chemotaxonomy of aerobic actinomycetes: phospholipid composition. Biochem Syst Ecol 5, 249-260.

Lechevalier, M. P., Prauser, H., Labeda, D. P. \& Ruan, J. S. (1986). Two new genera of nocardioform actinomycetes: Amycolata gen. nov. and Amycolatopsis gen. nov. Int J Syst Bacteriol 36, 29-37.

Li, W. J., Tang, S. K., Stackebrandt, E., Kroppenstedt, R. M., Schumann, P., Xu, L. H. \& Jiang, C. L. (2003a). Saccharomonospora paurometabolica sp. nov., a moderately halophilic actinomycete isolated from soil in China. Int J Syst Evol Microbiol 53, 15911594 . 
Li, W. J., Xu, P., Tang, S. K., Xu, L. H., Kroppenstedt, R. M., Stackebrandt, E. \& Jiang, C. L. (2003b). Prauserella halophila sp. nov. and Prauserella alba sp. nov., moderately halophilic actinomycetes from saline soil. Int $J$ Syst Evol Microbiol 53, 1545-1549.

Lu, Z., Liu, Z., Wang, L., Zhang, Y., Qi, W. \& Goodfellow, M. (2001). Saccharopolyspora flava sp. nov. and Saccharopolyspora thermophila sp. nov., novel actinomycetes from soil. Int J Syst Evol Microbiol 51, 319-325.

Mandel, M. \& Marmur, J. (1968). Use of ultraviolet absorbance temperature profile for determining the guanine plus cytosine content of DNA. Methods Enzymol 12B, 195-206.

Marmur, J. (1961). A procedure for the isolation of deoxyribonucleic acid from microorganisms. J Mol Biol 3, 208-218.

McVeigh, H. P., Divers, M., Warwick, S., Munro, J. \& Embley, T. M. (1994). Exploration of actinomycete diversity using ribosomal RNA sequences. Biotechnologia 7-8, 253-260.

Minnikin, D. E., O'Donnell, A. G., Goodfellow, M., Alderson, G., Athalye, M., Schaal, A. \& Parlett, J. H. (1984). An integrated procedure for the extraction of bacterial isoprenoid quinones and polar lipids. J Microbiol Methods 2, 233-241.

Morón, R., González, I. \& Genilloud, O. (1999). New genus-specific primers for the PCR identification of members of the genera Pseudonocardia and Saccharopolyspora. Int J Syst Bacteriol 49, 149162.

Nonomura, H. \& Ohara, Y. (1971). Distribution of actinomycetes in soil. X. New genus and species of monosporic actinomycetes. J Ferment Technol 49, 895-903.

Pimentel-Elardo, S. M., Tiro, L. P., Grozdanov, L. \& Hentschel, U. (2008). Saccharopolyspora cebuensis sp. nov., a novel actinomycete isolated from a Philippine sponge (Porifera). Int J Syst Evol Microbiol 58, 628-632.

Qin, S., Li, J., Zhao, G. Z., Chen, H. H., Xu, L. H. \& Li, W. J. (2008). Saccharopolyspora endophytica sp. nov., an endophytic actinomycete isolated from the root of Maytenus austroyunnanensis. Syst Appl Microbiol 31, 352-357.

Saitou, N. \& Nei, M. (1987). The neighbor-joining method: a new method for reconstructing phylogenetic trees. Mol Biol Evol 4, 406425.

Salazar, O., Morón, R. \& Genilloud, O. (2000). New genus-specific primers for the PCR identification of members of the genus Saccharomonospora and evaluation of the microbial diversity of wild-type isolates of Saccharomonospora detected from soil DNAs. Int J Syst Evol Microbiol 50, 2043-2055.

Sambrook, J. \& Russell, D. W. (2001). Molecular Cloning: a Laboratory Manual, 3rd edn. Cold Spring Harbor, NY: Cold Spring Harbor Laboratory.

Sasser, M. (1990). Identification of bacteria by gas chromatography of cellular fatty acids. USFCC Newsl 20, 16.

Shearer, M. C., Colman, P. M., Ferrin, R. M., Nisbet, L. J. \& Nash, C. H., III (1986). New genus of the Actinomycetales: Kibdelosporangium aridum gen. nov., sp. nov. Int J Syst Bacteriol 36, 47-54.

Shirling, E. B. \& Gottlieb, D. (1966). Methods for characterization of Streptomyces species. Int J Syst Bacteriol 16, 313-340.

Stach, J. E., Maldonado, L. A., Ward, A. C., Goodfellow, M. \& Bull, A. T. (2003). New primers for the class Actinobacteria: application to marine and terrestrial environments. Environ Microbiol 5, 828841.

Stackebrandt, E., Kroppenstedt, R. M., Jahnke, K.-D., Kemmerling, C. \& Gürtler, H. (1994). Transfer of Streptosporangium viridogriseum (Okuda et al. 1966), Streptosporangium viridogriseum subsp. kofuense (Nonomura and Ohara 1969), and Streptosporangium albidum (Furumai et al. 1968) to Kutzneria gen. nov. as Kutzneria viridogrisea comb. nov., Kutzneria kofuensis comb. nov., and Kutzneria albida comb. nov., respectively, and emendation of the genus Streptosporangium. Int J Syst Bacteriol 44, 265-269.

Stackebrandt, E., Rainey, F. A. \& Ward-Rainey, N. L. (1997). Proposal for a new hierarchic classification system, Actinobacteria classis nov. Int J Syst Bacteriol 47, 479-491.

Staneck, J. L. \& Roberts, G. D. (1974). Simplified approach to identification of aerobic actinomycetes by thin-layer chromatography. Appl Microbiol 28, 226-231.

Syed, D. G., Tang, S. K., Cai, M., Zhi, X. Y., Agasar, D., Lee, J. C., Kim, C. J., Jiang, C. L., Xu, L. H. \& Li, W. J. (2008). Saccharomonospora saliphila sp. nov., a halophilic actinomycete from an Indian soil. Int $J$ Syst Evol Microbiol 58, 570-573.

Tamura, T., Liu, Z., Zhang, Y. \& Hatano, K. (2000). Actinoalloteichus cyanogriseus gen. nov., sp. nov. Int J Syst Evol Microbiol 50, 14351440.

Tamura, K., Dudley, J., Nei, M. \& Kumar, S. (2007). MEGA4: molecular evolutionary genetics analysis (MEGA) software version 4.0. Mol Biol Evol 24, 1596-1599.

Tan, G. Y., Ward, A. C. \& Goodfellow, M. (2006). Exploration of Amycolatopsis diversity in soil using genus-specific primers and novel selective media. Syst Appl Microbiol 29, 557-569.

Thompson, J. D., Gibson, T. J., Plewniak, F., Jeanmougin, F. \& Higgins, D. G. (1997). The CLUSTAL_X windows interface: flexible strategies for multiple sequence alignment aided by quality analysis tools. Nucleic Acids Res 25, 4876-4882.

Tian, X. P., Zhi, X. Y., Qiu, Y. Q., Zhang, Y. Q., Tang, S. K., Xu, L. H., Zhang, S. \& Li, W. J. (2009). Sciscionella marina gen. nov., sp. nov., a marine actinomycete isolated from a sediment in the northern South China Sea. Int J Syst Evol Microbiol 59, 222-228.

Tomita, K., Uenoyama, Y., Numata, E. I., Sasahira, T., Hoshino, Y., Fujisawa, K. I., Tsukiura, H. \& Kawaguchi, H. (1978). Streptoalloteichus, a new genus of the family Actinoplanaceae. J Antibiot (Tokyo) 31, 497510 .

Tseng, M., Yang, S. F., Li, W. J. \& Jiang, C. L. (2006). Amycolatopsis taiwanensis sp. nov., from soil. Int J Syst Evol Microbiol 56, 18111815.

Uchida, K., Kudo, T., Suzuki, K. I. \& Nakase, T. (1999). A new rapid method of glycolate test by diethyl ether extraction, which is applicable to a small amount of bacterial cells of less than one milligram. J Gen Appl Microbiol 45, 49-56.

Van de Peer, Y. \& De Wachter, R. (1994). TREECON for Windows: a software package for the construction and drawing of evolutionary trees for the Microsoft Windows environment. Comput Appl Biosci 10, 569570 .

Van de Peer, Y. \& De Wachter, R. (1997). Construction of evolutionary distance trees with TREECON for Windows: accounting for variation in nucleotide substitution rate among sites. Comput Appl Biosci 13, 227-230.

Xu, P., Li, W. J., Xu, L. H. \& Jiang, C. L. (2003). A microwave-based method for genomic DNA extraction from actinomycetes. Microbiology [English translation of Microbiology (Beijing)] 30, 8284.

Yoon, J. H., Lee, K. C., Shin, Y. K. \& Park, Y. H. (2000). Transfer of 'Thermoactinomyces glaucus' IFO 12530 and 'Thermoactinomyces monosporus' IFO 14050 to the genus Saccharomonospora as members of Saccharomonospora glauca. J Gen Appl Microbiol 46, 251-256.

Zhang, J., Wu, D., Zhang, J., Liu, Z. \& Song, F. (2008). Saccharopolyspora shandongensis sp. nov., isolated from wheat-field soil. Int J Syst Evol Microbiol 58, 1094-1099. 
Zhi, X. Y., Li, W. J. \& Stackebrandt, E. (2009). An update of the structure and 16S rRNA gene sequence-based definition of higher ranks of the class Actinobacteria, with the proposal of two new suborders and four new families and emended descriptions of the existing higher taxa. Int J Syst Evol Microbiol 59, 589-608. 